$14^{\text {th }}$ Conf. Agric. Develop. Res., Fac. of Agric., Ain Shams Univ., March, 2019, Cairo, Egypt

Special Issue, 27(1), 395 - 404, 2019

Website: http://strategy-plan.asu.edu.eg/AUJASCI/

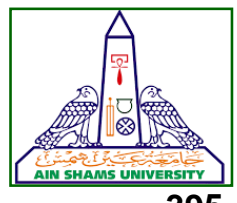

\title{
AN ASSESSMENT STUDY OF GROWTH PERFORMANCE AND GON- ADS DEVELOPMENT OF MONO SEX NILE TILAPIA IN DIFFERENT AGE STAGES DURING THE PRODUCTION PERIOD
}

\author{
Sara S. El-Nahal ${ }^{*}$, Amer M.A., Osman M.F. and Ali T.A. \\ Animal Production Dept., Fac. of Agric., Ain Shams Univ., P.O. Box 68, Hadayek Shobra \\ 11241, Cairo, Egypt
}

*Corresponding author: sarashahat@agr.asu.edu.eg

Received 3 March, 2019, $\quad$ Accepted 12 March, 2019

\begin{abstract}
The objective of this study was to follow up the growth performance and gonads development of sex reversed male Nile tilapia. Fish fed commercial diet contained $30 \%$ crude protein at a rate of $3 \%$ of the biomass and 10 fish were randomly taken biweekly during the experimental period (16 weeks). Growth performance, feed utilization and survival rate were calculated. Histological examination of the gonads was done every two weeks to follow the growth and development of the gonads. Results showed positive interactions between growth parameters and reproductive development during different periods of fish productive cycle. Histological examination illustrated that during early ages, testicular sections of mono sex male's tilapia had abnormal architecture with deterioration of germinative tissue. Despite abnormal testis texture, fish started spermatogenesis, a step toward puberty when their body weight reached $29.16 \mathrm{~g}$. As fish reached 4-5 months, male start to recover their testes normal structures and at age of 5.5-6 months, testicular sections appeared normally as pointed out by firmed testicular lobules, existence of all germ cell types and the intensively stored spermatozoa in testicular lumen and testicular ducts, confirming the full maturity of males. Based on the obtained results, it can clearly conclude that there is a relationship between age, body weight and development of sexual glands. It has also been shown that the hormonal treatment of tilapia seeds in the early stages for production of mono sex (all males) leads to a marked deterioration in the testes structure, continues near the fish enters the sexual maturity. At a later age, males can overcome this deterioration, restore the histological
\end{abstract}

structure of the testes and achieve full sexual maturity at the age around from 5.5 to 6 months.

Keywords: Nile tilapia, mono sex, gonads histology, growth

\section{INTRODUCTION}

Problem associated with rearing mixed sex of Nile tilapia, Oreochromis niloticus is the early maturation and its ability to breed at young age and small sizes. These characteristics result in the overpopulation of stocked tilapia in ponds and the stunting of growth because of the crowding of the fish (Fashina-Bombatta and Megbowon, 2012). Moreover, the sizes of the fish at harvest, varying from small to large due to the faster growth of males. This makes it more difficult to establish uniformity of the product. Tilapia producers lock for high yields of large-sized fish within 6 months, therefore, all male fry is preferred. Androgens are usually used to induce sex inversion, a common technique used to obtain all-male population (Lone and Matty 1980, Mires, 1995, Gale et al 1999, Megbowon and Mojekwu, 2014). All-male mono sex tilapia produced by 17- $\alpha$-methyltestosterone, a synthetic androgen, is an outspreading technique for the commercial aquaculture due to not only high growth of male and better feed conversion, but also to disrupt the early spawning of tilapia. Since steroid hormones also could be used as growth promoter in fish, where they enhanced the weight gain of fish and improved the rate of muscle protein accretion (Higgs et al 1977, Donaldson et al 1979 and Ahmed et al 2002). Sexual maturity has a major role in regulating growth and leads to significant changes in body composition. During 
periods of tilapia development patterns growth vary between males as they increase in age and sexual maturation (Bhatta et al 2012). The present study was carried out in order to correlate body growth with puberty and sexual maturity of male Nile tilapia, O. niloticus, besides follow up gonadal development of sex reversed males during the production periods for 4 months.

\section{MATERIALS AND METHODS}

The experimental fish (all male Nile tilapia, $O$. niloticus) were purchased from a private hatchery at Kafr El Sheikh Governorate, Egypt and stocked in a concrete pond $(32 \mathrm{~m} \times 13 \mathrm{~m} \times 1.5 \mathrm{~m}$ depth) belongs to Fish Production Branch, Department of Animal Production, Faculty of Agriculture, Ain Shams University, Cairo, Egypt. This concrete pond was filled with a mixture of undergroundwater and Nile water and 30,000 fry of mono sex Nile tilapia were stocked at a density of $50 \mathrm{fry} / \mathrm{m}^{3}$ during May 2017. A 2.25 HP paddle wheel and 3HP air blower were used to aerate the pond with the needed oxygen.

\section{Experimental diet}

In the present study, fish fed a floated commercial diet containing $30 \%$ crude protein (CP) three times daily (six days a week) at a rate of $3 \%$ of their total biomass. Table 1 showed the composition and the chemical analysis of the commercial diet used in the experiment.

Table 1. Composition and chemical analysis of the commercial diet used in the experiment

\begin{tabular}{|l|c|}
\hline Composition & $\%$ \\
\hline Soy bean meal (46\% CP) & 28.0 \\
Wheat middling & 15.0 \\
Wheat brane & 12.0 \\
Fish meal (60\% CP) & 10.0 \\
Yellow corn & 18.0 \\
Corn gluten & 10.0 \\
Calcium diphosphate & 2.0 \\
Fish oil & 2.0 \\
Soy oil & 2.7 \\
*Premix (3451) & 0.3 \\
\hline Chemical analysis & on DM basis \\
\hline Crude protein (CP, \%) & 30.2 \\
Ether extract (EE, \%) & 6.3 \\
Crude fiber (CF, \%) & 4.5 \\
Ash (\%) & 6.1 \\
Nitrogen free extract (NFE, \%) & 52.9 \\
Gross energy (GE) (kcal/kg feed) & 4100 \\
\hline
\end{tabular}

*One kg premix contained:

Vitamins: $48 \times 10^{5} \mathrm{I} . \mathrm{U}(\mathrm{A}), 6 \times 10^{2} \mathrm{mg}\left(\mathrm{B}_{6}\right), 20 \mathrm{mg}$

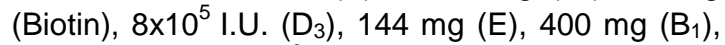
$1600 \mathrm{mg}\left(\mathrm{B}_{2}\right), 4 \times 10^{3} \mathrm{mg}$ (Pantothenic acid), $4 \mathrm{mg}$ $\left(\mathrm{B}_{12}\right), 4 \times 10^{2} \mathrm{mg}$ (Niacin), $2 \times 10^{5} \mathrm{mg}$ (Choline chloride), and $400 \mathrm{mg}$ (folic acid).

Minerals: $12 \times 10^{3} \mathrm{mg}$ Iron, $16 \times 10^{3} \mathrm{mg}$ Manganese, $12 \times 10^{2} \mathrm{mg}$ Copper, $120 \mathrm{mg}$ lodine, $80 \mathrm{mg}$ Cobalt, $40 \mathrm{mg}$ Selenium, and $16 \times 10^{3} \mathrm{mg}$ Zinc.

${ }^{*}$ NFE $=$ Nitrogen free extract $(100-[C P+$ Ash + $C F+E E)]$.

${ }^{\star}$ GE $=$ Gross Energy calculated as 5.65, 9.45, and $4.12 \mathrm{Kcal} / \mathrm{gram}$ dry matter of protein, lipid and carbohydrates, respectively, after (NRC, 2011).

\section{Water quality parameters}

Water quality parameters were measured by using Nilebot ${ }^{\circledR}$ system, where water temperature, $\mathrm{pH}$ and dissolved oxygen (DO) were measured, recorded and sent online every 3 hours. Total ammonia concentration was measured by $\mathrm{HACH}$ comparison apparatus using HACK kits (Hach Co., Loveland, Colorado, USA). The percentages of unionized ammonia $\left(\mathrm{NH}_{3}\right)$ was calculated from multiplying the total ammonia value by the appropriate factor according to the following equation:

Ammonia concentration (mg/L as $\left.\mathrm{NH}_{3}\right)=\mathrm{A} /$ $100 \times 1.2 \times$ total ammonia.

Where, $\mathrm{A}$ is a coefficient related to water $\mathrm{pH}$ and temperature.

\section{Fish sampling}

Ten fish were randomly taken every 15 days throughout the experimental period that started from $26 / 7 / 2017$ to $15 / 11 / 2017$. Fish were weighed every two weeks to measure growth performance and to recalculate the daily feed allowances. Fish growth performance parameters such as total weight gain, total length (TL), thickness, width, average daily gain (ADG), specific growth rate (SGR), feed conversion ratio (FCR), protein efficiency ratio (PER) and protein productive value (PPV) were measured. Gonads samples for ordinary histological examination were also taken biweekly.

Fish growth performance and feed utilization parameters were calculated according to Cho and Kaushik (1986) as following:

Average weight gain $(A W G)=$ Final weight $(g / f i s h)$ - initial weight ( $g /$ fish). 
Average daily gain (ADG, g / fish / day) = AWG (g) / experimental period (days).

Specific growth rate (SGR, \%/day) = $100($ In final weight - In initial weight) / experimental period (day).

Feed conversion ratio $(F C R)=$ Feed intake $(g) /$ body weight gain $(\mathrm{g})$.

Protein efficiency ratio $($ PER $)=$ Gain in weight (g) / protein intake (g)

Protein productive value (PPV, \%) $=100$ [protein gain $(\mathrm{g}) /$ protein intake $(\mathrm{g})$ ].

\section{Chemical analyses}

Samples of the experimental diets and fish were chemically analyzed according to the AOAC (2012) Official Methods. Where, dry matter (DM) after drying in an oven at $105^{\circ} \mathrm{C}$ until constant weight; crude protein $(\mathrm{N}=6.25)$ by Kjeldahl digestion and distillation after acid digestion; crude lipid by petroleum ether extraction in a Soxhlet extractor apparatus; ash by incineration in a muffle furnace at $550^{\circ} \mathrm{C}$ for $4 \mathrm{~h}$. Nitrogen free extract (NFE) was calculated by differences, by deducting the sum of percentages of CP, EE, CF and ash from 100.

\section{Histological examination}

The fish gonads were dissected into small pieces and fixed in formalin $10 \%$ solution for 24 hours. Later, fragments were preserved in $70 \%$ ethanol, then dehydrated through an ascending series of alcohol, embedded and blocked in paraffin wax. Fine transverse sections of $5 \mu$ were cut and stained with ordinary hematoxylin $(\mathrm{H})$ and eosin (E) protocol according to Genten et al. (2009). The tissue slides were examined by light microscope and were photographed by a fluorescence Leica DM2500 Germany.

\section{Statistical analysis}

The data of growth parameters were subjected to one-way analysis of variance using SPSS-20 and expressed as means $\pm S E$. Significance was accepted at $\mathrm{P}<0.05$.

\section{RESULTS AND DISCUSSION}

\section{Water quality}

During the experimental periods water quality parameters were within the normal levels suitable for tilapia fish (EI-Sayed, 2006), where, water tem- perature was maintained at $28 \pm 2^{\circ} \mathrm{C}$; $\mathrm{pH}$ was $8 \pm$ 0.2 ; dissolved oxygen (DO) was $5.5 \pm 0.5 \mathrm{mg} / \mathrm{L}$ and total ammonia was $0.0009 \pm 0.0001 \mathrm{mg} / \mathrm{L}$.

\section{Growth performance}

To investigate the state of growth, the differences between fish were analyzed every two weeks started from two months' age till fish reached six months' age. The body weight was found to be increased throughout the experimental period, where fish were able to double their weigh every 4 weeks. The initials fish TL were $9.30 \pm$ $0.14 \mathrm{~cm}$; BW1 $6.33 \pm 0.71 \mathrm{~g}$; thickness $1.50 \pm 0.0$ $\mathrm{cm}$ and width $3.16 \pm 0.06 \mathrm{~cm}$, while the final fish $\mathrm{TL}, \mathrm{BW}$, thickness and width were $19.71 \pm 0.48$ $\mathrm{cm}, 173 \pm 8.58 \mathrm{~g}, 3.21 \pm 0.09 \mathrm{~cm}$ and $7.03 \pm 0.15$ $\mathrm{cm}$, respectively (Table 2 ).

Table 2. Mean \pm SE of body measurements of mono sex male Nile tilapia throughout the experimental periods

\begin{tabular}{|c|c|c|c|c|}
\hline $\begin{array}{c}\text { Sample } \\
\text { No. }\end{array}$ & $\begin{array}{c}\text { Body } \\
\text { weight } \\
(\mathrm{g} / \text { fish })\end{array}$ & $\begin{array}{c}\text { Total length } \\
(\mathrm{cm})\end{array}$ & $\begin{array}{c}\text { Width } \\
(\mathrm{cm})\end{array}$ & $\begin{array}{c}\text { Thickness } \\
(\mathrm{cm})\end{array}$ \\
\hline \multirow{2}{*}{ Initial } & 16.33 & 9.30 & 3.16 & 1.50 \\
& \pm 0.71 & \pm 0.14 & \pm 0.06 & \pm 0.00 \\
1 & 23.33 & 10.06 & 3.31 & 1.51 \\
& \pm 1.08 & \pm 0.14 & \pm 0.10 & \pm 0.06 \\
2 & 29.16 & 11.11 & 3.31 & 1.51 \\
& \pm 2.38 & \pm 0.41 & \pm 0.14 & \pm 0.06 \\
3 & 48.16 & 13.31 & 4.46 & 2.05 \\
& \pm 3.33 & \pm 0.39 & \pm 0.15 & \pm 0.03 \\
4 & 54.66 & 14.00 & 4.70 & 2.10 \\
& \pm 1.68 & \pm 0.08 & \pm 0.08 & \pm 0.04 \\
5 & 62.83 & 14.13 & 4.70 & 2.15 \\
& \pm 4.11 & \pm 0.23 & \pm 0.20 & \pm 0.05 \\
6 & 68.33 & 14.23 & 4.81 & 2.20 \\
& \pm 11.06 & \pm 0.74 & \pm 0.33 & \pm 0.12 \\
7 & 107.66 & 16.08 & 5.65 & 2.45 \\
& \pm 6.46 & \pm 0.25 & \pm 0.15 & \pm 0.09 \\
\hline \multirow{2}{*}{ Final } & 173.16 & 17.23 & 7.03 & 3.21 \\
& \pm 11.06 & \pm 0.74 & \pm 0.15 & \pm 0.09 \\
\hline
\end{tabular}

Values within each column (between periods) are statistically deifferent $(P<0.05)$.

Data of fish growth rate and feed utilization throughout the experimental periods are presented in Table (3). These results are corresponding to those reported by Marjani et al (2009), who revealed that, all male $O$. niloticus recorded higher growth performance in terms of final BW, standard length, weight gain, SGR, feed utilization parameters and survival rate. 
Table 3. Growth performance and feed efficiency of mono sex male Nile tilapia throughout the whole experimental period (4 months)

\begin{tabular}{|c|c|c|c|c|c|c|c|c|c|c|}
\hline Item & $\begin{array}{c}\text { Initial } \\
\text { weight } \\
\text { (g/fish) }\end{array}$ & $\begin{array}{c}\text { Final } \\
\text { weight } \\
\text { (g/fish) }\end{array}$ & $\begin{array}{c}\text { Total } \\
\text { gain } \\
\text { (g/fish) }\end{array}$ & ADG & SGR & $\begin{array}{c}\text { Feed } \\
\text { intake } \\
\text { (g/fish) }\end{array}$ & FCR & PER & PPV & $\begin{array}{c}\text { Survival } \\
\text { rate } \\
(\%)\end{array}$ \\
\hline Mean & $\begin{array}{c}16.33 \\
\pm 0.71\end{array}$ & $\begin{array}{c}173.16 \\
\pm 8.58\end{array}$ & $\begin{array}{c}156.83 \\
\pm 7.87\end{array}$ & 1.31 & 1.97 & 283.84 & 1.63 & 2.47 & 44.45 & 98 \\
\hline
\end{tabular}

Growth patterns of male Nile tilapia was changed (Figure 1) with increasing age and sexual maturity. The males began to grow rapidly at three months age, with the onset of spermatogenesis. The results showed that SGR of male Nile tilapia was $1.9,2.1,2.06$ and 3.11 for the first, second, third, and fourth intervals (every four weeks), respectively (Figure 2).

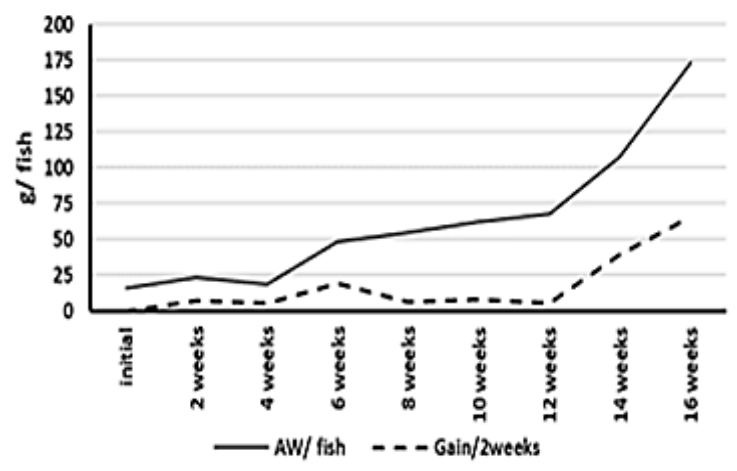

Fig. 1. Average weight (AW) and weight gain every two weeks intervals of mono sex male $O$. niloticus.

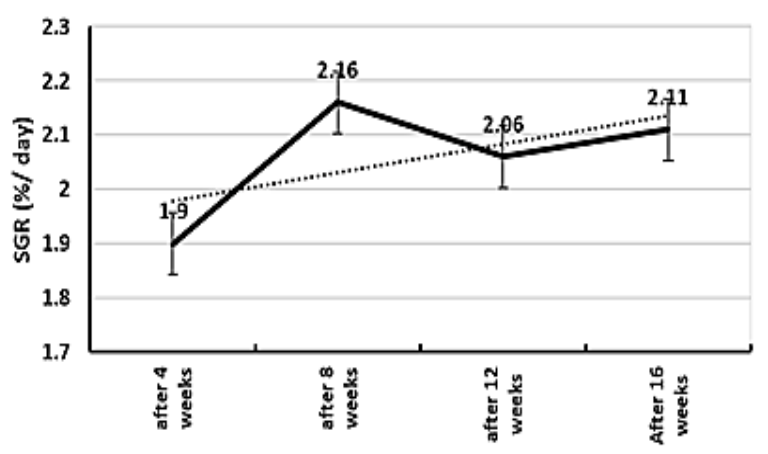

Fig. 2. Specific growth rate $(\% / d)$ of mono sex male $O$. niloticus every 4 weeks intervals during the experimental period.

Similar values were recorded by Workagegn et al (2014) who found that SGR of Nile tilapia was
$3.2 \% /$ day. The results of Alhassan et al (2018) showed that SGR of $O$. niloticus fingerlings weighed (17.43-24.75 g/fish) was $2.51 \% /$ day, however, with smaller fish (2.03-7.26 g/fish) value of SGR was higher than that of larger fish.

Chemical composition analyses of the experimental fish are presented in Table (4), where moisture at the end of the experiment was $75.4 \%$, body protein content was increased with increasing age, body lipid was changing with age, the highest lipid content was recordrd for three months aged fish while the lowest lipid content was recorded in fish aged six months. Ash content was increased with incerasing age, the highest ash percentage was recorded in six months aged fish.

Table 4: Chemical composition (\% on dry matter basis) of the whole fish body at the end of the experiment

\begin{tabular}{|c|c|c|c|c|}
\hline Item & $\begin{array}{c}\text { Moisture } \\
(\%)\end{array}$ & $\begin{array}{c}\text { Crude } \\
\text { Protein (\%) }\end{array}$ & $\begin{array}{c}\text { Lipid } \\
(\%)\end{array}$ & $\begin{array}{c}\text { Ash } \\
(\%)\end{array}$ \\
\hline Initial & 76.10 & 66.35 & 25.13 & 6.45 \\
\hline Final & 75.40 & 72.90 & 21.70 & 7.50 \\
\hline
\end{tabular}

\section{Gonads development}

The examined testicular sections were classified into several distinct spermatogenic stages according to the most developed germ cells according to Kosai et al (2011) as follow: Stage I: Immature testes were recognized by the absence of spermatogenic activity in the germinative tissue compartment and the presence of primarily spermatogonia. Stage II: Early spermatogenesis was characterized by germ cell proliferation and differentiation (spermatocytes to spermatids). Stage III: mid-spermatogenesis, the germinative tissue compartment was moderately thick and active germ cell differentiation could be observed; spermatocytes, spermatids and spermatozoa were present 
in roughly equal proportion. Stage IV: Late spermatogenesis, the germinative tissue compartment was thick, although all germ cell types were existing, spermatozoa predominate in this stage. Stages from II to IV were characteristic of pubertal and sexually mature fish, with the least activity occurring in immature or offseason (stage II) and the most activity taking place immediately prior to and during the spawning season (stage IV).

The current study was carried out to follow-up the development of gonads of mono sex male tilapia in relation to body growth during the productive periods. At two months' age gonads histological observations of $O$. niloticus were detected as shown in Figure 3, where the appearance of testicular architecture was not firmed with deterioration of germinative layer of some testicular lobules, these findings could be due to the hormonal sex reversal applied during the fry stage (Abdelhamid et al 2009). The authors mentioned that the histological examination of testis of 17-a-methylt estosterone treated $O$. niloticus showed slight atrophy, abnormal structure and depression of seminiferous tubules, degeneration of spermatogenetic layer of some seminiferous tubules and disappearance regions of some seminiferous tubules. Nevertheless, in the present study the lobules of testicular section (Figure 3) appeared to contain some spermatogenic cysts at different stages of development, which mean spermatogenesis was started. Each spermatogenic cyst enclosed only one type of germ cells at the same stage of development. At this age fish body weight and fish body length were $16.3 \mathrm{~g}$ and $9.3 \mathrm{~cm} / \mathrm{fish}$, respectively.

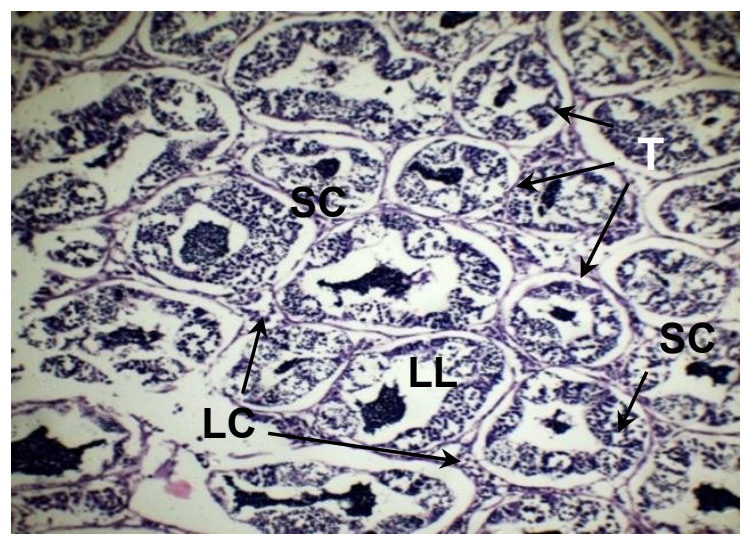

Fig. 3. Testicular transverse section of two months age mono sex $O$. niloticus males stained with $\mathrm{H} \& \mathrm{E}$ (10X), illustrates an abnormal overview of testicular formation, deterioration of testicular lobules and germinative epithelium. Testicular lobules (TL), spermatogenic cysts (SC), lobular lumen (LL) and Leydig cells (LC).
Similar histological findings were also observed in testicular sections of males aged 2.5, 3- and 3.5months (Figures 4 A; B and C, respectively). Despite the abnormal testicular architecture, photomicrographs showed that after starting the meiosis, the spermatocytes were subjected to produce some scattered spermatid cysts (Figure 4). At this histological phase, mean of fish BW and TL were $48.16 \mathrm{~g}$ and $13.31 \mathrm{~cm}$, respectively.

With increasing fish BW and TL reaching mean values of $68.33 \mathrm{~g}$ and $14.23 \mathrm{~cm}$, respectively, mono sex $O$. niloticus males aged $4,4.5$ and 5 months began to recover their normal testes architectures, where testicular lobules and spermatogenic cysts appeared normally (Figures 5 A; B and $\mathbf{C}$ ). All germ cell type cysts are existed including spermatogonia, spermatocyte and spermatids in addition to spermatozoa meaning the active spermatogenesis stage and spermiogenesis process.

When fish reached an averages BW of 173.16 $\mathrm{g}$ and TL of $17.23 \mathrm{~cm}$, photomicrographs of their testicular sections appeared normally in texture, indicating that mono sex $O$. niloticus males after sex reversal at fry stage by 17- $\alpha$ - methyltestosterone can reach full sexual maturity at 5.5 to 6 months of age (Figures 6 A and B) as indicating by the intensively existence of spermatozoa in testicular lumen and testicular ducts. The expansion of the efferent and testicular ducts and its filled with spermatozoa were observed when males reached 5.5 - 6 months indicating full gonad maturation and milt could be acquired by hand-stripping (Figure 6). Thus, as fish BW increases with the advancing of fish age, gonads of mono sex $\mathrm{O}$. niloticus males completely developed, and fish reaches the full sexual maturity, hence gonadal development is positively correlated with $\mathrm{BW}$ gain as previously mentioned by Abdelhamid et al (2010).

The stage of development in which the individual is able to reproduce sexually is called puberty, it is the developmental period which includes the transition from an immature state to a mature state of the reproductive system (Kosai et al 2011)). It is characterized by the activation of the brain-pituitary gonadal axis (BPG). In vertebrates, including nonmammals, germ cell maturation and development appear in a similarity (Pudney, 1995). Spermatogenesis can be divided into distinct sequential stages as follows: mitotic renewal of stem cells, mitotic proliferation of spermatogonia and supporting cells (e.g., Leydig and Sertoli cells), meiosis of germ cells to haploid spermatids and spermiogen- 

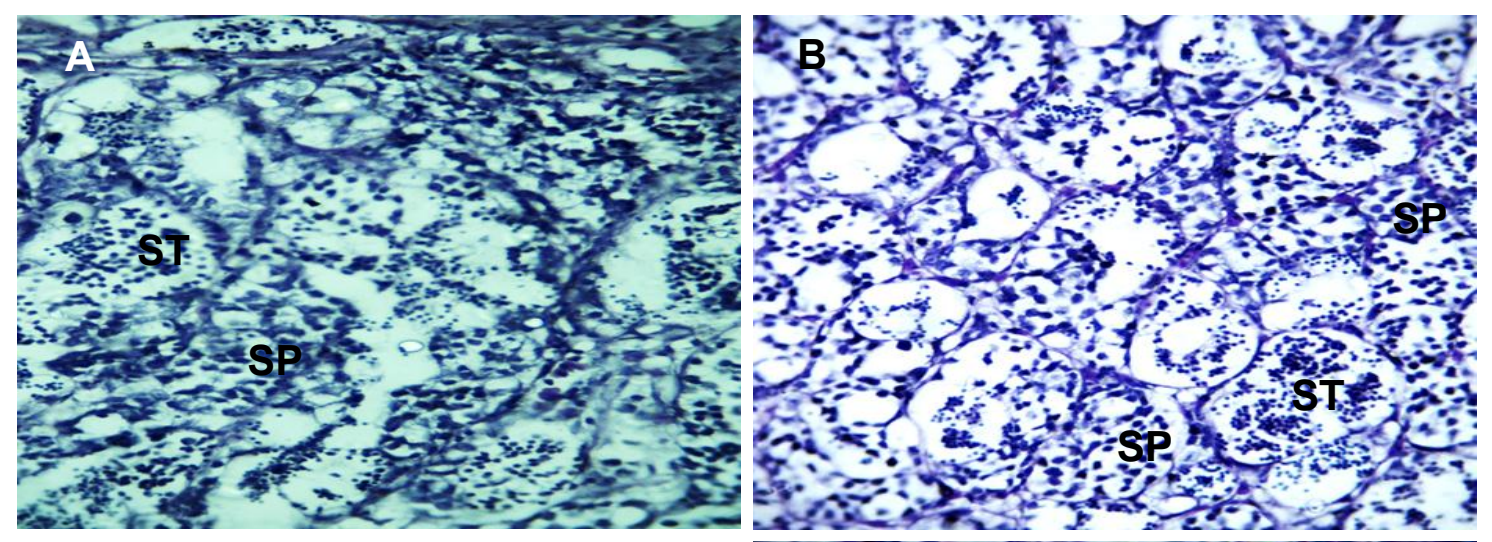

Fig. 4 A - C: Testicular sections of mono sex $O$. niloticus males aged 2.5 months (A); 3 months (B) and 3.5 months (C) stained with H\&E (40X), illustrating that, despite abnormal testicular architecture, spermatocytes (SP) and scattered spermatid (ST) are existed.
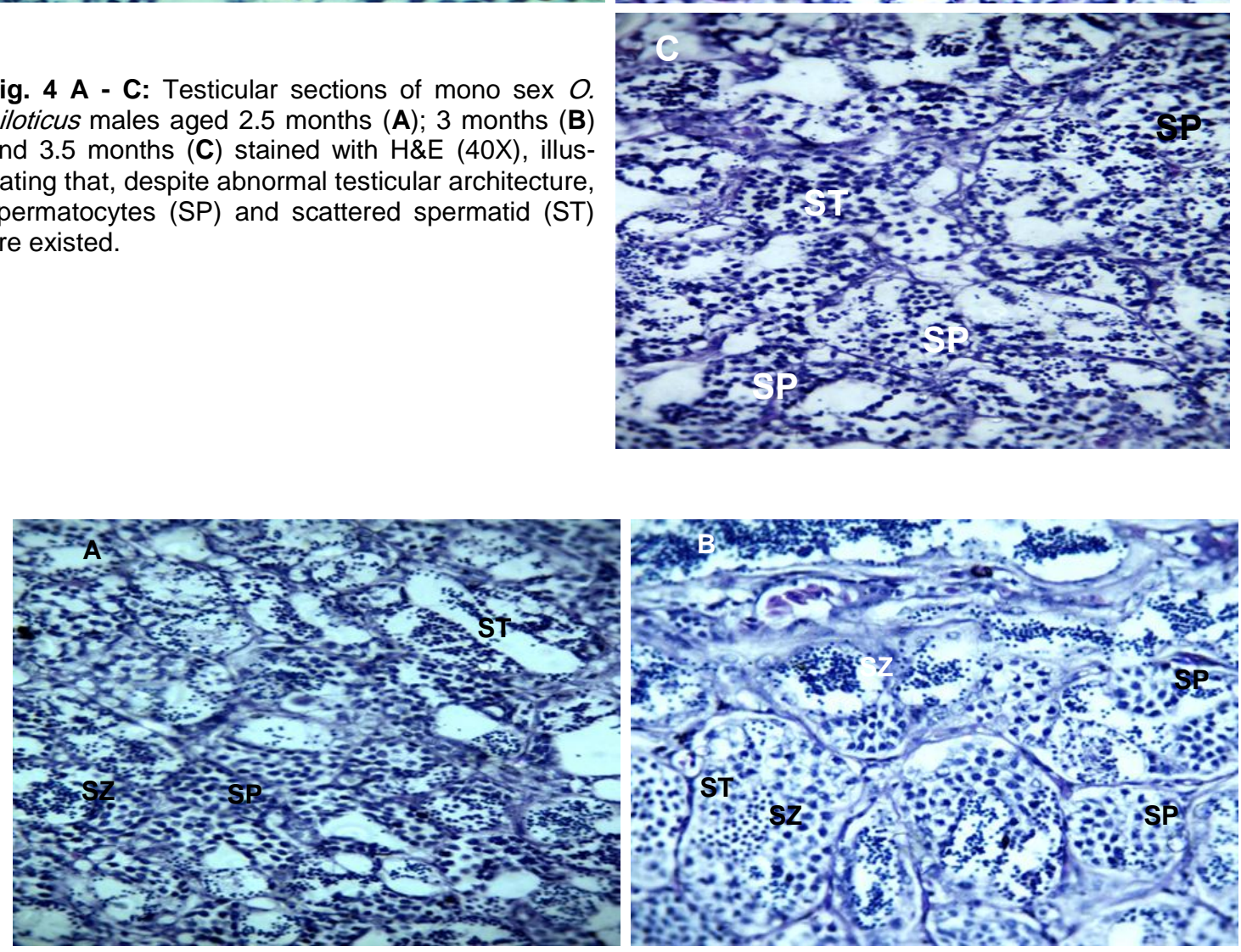

Fig. 5 A - C: Testicular sections of mono sex males aged 4 months $(\mathbf{A}) ; 4.5$ months $(\mathbf{B})$ and 5 months (C) stained with H\&E (40X), showing testicular recovery into normal structure as appointed by firmed lobules and the exitance of all germ cell types: spermatogonia (SG), spermatocytes (SP), spermatid (ST), and spermatozoa (SZ) in lobular lumen (LL) and testicular duct (TD).

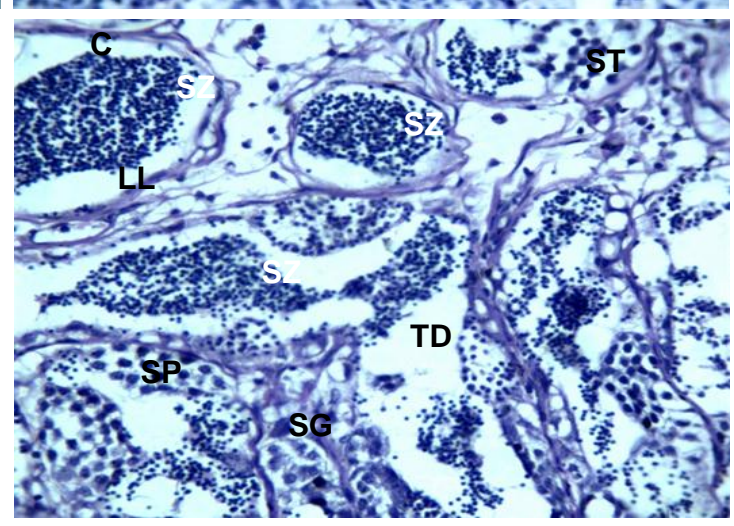



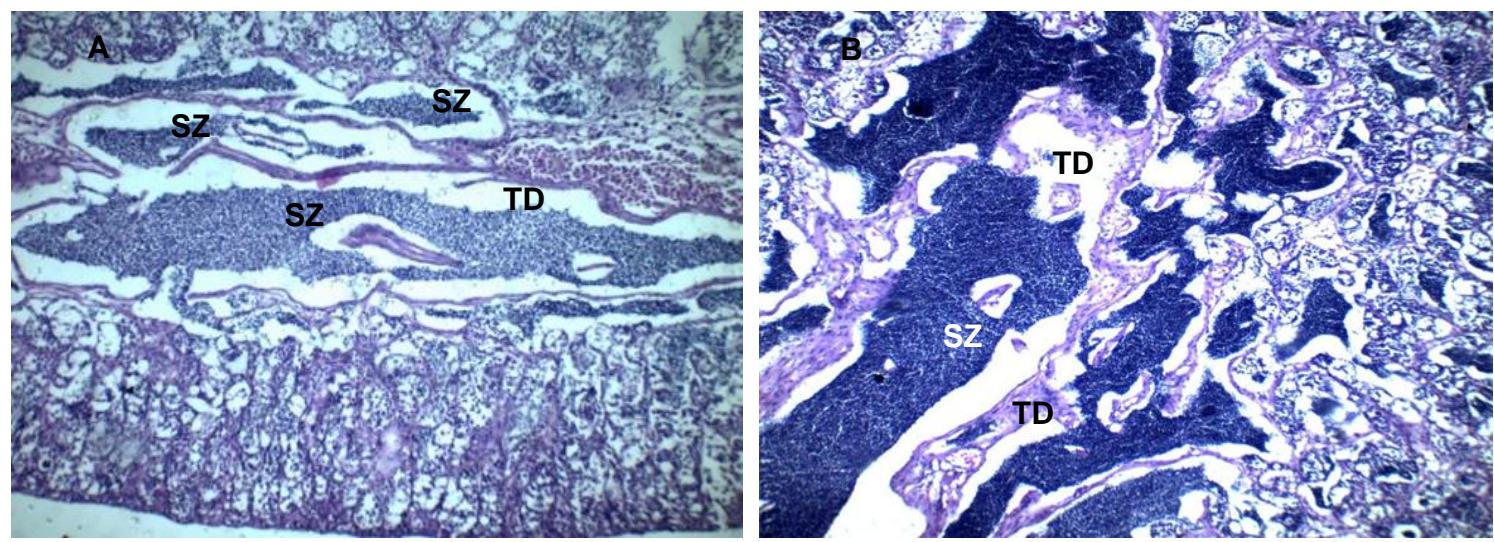

Fig. 6 A - B: Testicular transverse sections of mono sex male aged 5.5 months (A) and 6 months (B) stained with $\mathrm{H} \& \mathrm{E}(10 \mathrm{X})$, showing full recovery of testicular structure, testicular lumens and ducts (TD) are intensively filled with spermatozoa (SZ).

esis (the transition of spermatids into fully functional spermatozoa) (Miura et al 1991 \& 2001 and Loir, 1999 and Schulz et al 2010).

In tilapia fry stage, undifferentiated gonads contained only somatic cells and primordial germ cells which later developed into spermatogonia. With the onset of spermatogenesis, spermatogonia stem cells proliferate for self-renewal and to multiply their numbers. Spermatogonia type $A$ and type $B$ are located on the edge of testicular lobules and a part of their Sertoli cells were attached to the basement membrane forming spermatogenic cyst. Concomitantly, multiplication of germ cell within each cyst takes place, and this development is paralleled by the elongation of testicular lamellae and rapidly differentiate into spermatocytes that entranced to meiotic divisions, which observed around age of two months (Figure 3). After the initiation of meiosis, cells rapidly underwent to spermatids, then processed through spermiogenesis, a morphological metamorphosis process to form spermatozoa. Around 3 months age, asynchronously all forms of spermatogenic cells spermatogonia (SG), spermatocyte (SC), spermatids (ST) and a few cysts of spermatozoa (SZ) were presented in testis (Figure 4), the same results were mentioned by Msiska (2002).

Present observations of histological study revealed that testis of hormonal reversed mono sex male Nile tilapia during early stages of development appeared abnormal in its architectures with abnormal testicular lobule and spermatogenic cysts. These findings agree with Magouz et al (2000) and Abdelhamid et al (2009) who found that 17-a-methyltestosterone hormonal treatment resulted in abnormal structure of the tilapia fish testis including seminiferous tubules degeneration and atrophy of the interstitial tissue. In the present study, histological observations reveled that mono sex male Nile tilapia recovered their normal testicular structure with increasing body weight and by the advancing of age a full maturity was reached at age of 5.5 to 6 months as indicating by the intensive existence of spermatozoa in testicular lumens and testis ducts. Reversely, Ebada (2004) reported that the use of 17-a-methyltestosterone with tilapia fry caused sterility, in term of separation of the spermatogenetic layers from the basement membrane of the seminiferous tubules of the testes. Moreover, the author mentioned that seminiferous tubules are free from spermatogenetic layers and the interstitial was almost free from Leydig cells. The last author added that there were no spermatozoa in the lumen of the seminiferous tubules in Nile tilapia sex reversed male fish.

\section{CONCLUSION}

Based on the above obtained results, it could be clearly concluded that there is a strong relationship between age, BW, growth and development of $O$. niloticus sexual glands. It has been also shown that the hormonal treatment of tilapia seeds in the early stages for single sex production (all-males) leads to a marked deterioration in testicular structure that continues until the fish begin to enter sexual maturity, then and at a later age, males can overcome this deterioration and restore the testicular structure and achieve full sexual maturity at the age around from 5.5 to 6 months. 


\section{REFERENCES}

Abdelhamid, M.A., Mehrim, A.I., El-Barbary, M.I. and El-Sharawy, M.A., 2010. An attempt to improve the reproductive efficiency of Nile tilapia brood stock fish. Fish Physiol. Biochem., 36 (4), 1097-1104.

Abdelhamid, M.A., Mehrim, A.I., Salem, M.F.I. and Yosuf, H.A.E., 2009. All-Male Mono sex Nile Tilapia (Oreochromis Niloticus), Pros and Cons. Egypt J. Basic Appl. Physiol., 8 (1), 41-57.

Ahmad, M.H., Abdel-Tawwab, M., Shalaby, A.E.E. and Khattab, Y.A.E., 2002. Effects of 17a-Methyl testosterone on growth performance and some physiological changes of Nile tilapia, Oreochromis niloticus L. fingerlings. Egypt J. Aqua. Biol. Fish., 6(2), 1-23.

Alhassan, E. H., Kombat, E.O. and Karim, D., 2018. Growth Performance of the Nile Tilapia, Oreochromis niloticus Cultured in Cages in Two Dams in the Bongo District of Ghana. West African J. of Applied Ecology, 26(1), 11-21.

AOAC, 2012. Official Methods of Analysis of AOAC international. 19 ${ }^{\text {th }}$ Ed., AOAC International, Gaithersburg, Maryland, US.

Bhatta, S., Iwai, T., Miura T., Higuchi, M., Maugars, G. and Miura, C., 2012. Differences between male and female growth and sexual maturation in tilapia (Oreochromis mossabicus). Journal of Science, Engineering and Technology, 8, 57-65.

Cho, C.Y., Kaushik, S.J., 1986. Effects of protein intake on metabolizable and net energy values of fish diets. In: Cowey, C.B., Mackie, A.M., Bell, J.B. (eds.), Fish feeding and Nutrition. Academic Press, London. pp. 95-117.

Donaldson, E.M., Fagerlund, U.H.M., Higgs, D.A. and McBride, J.R., 1979. Hormonal enhancement of growth. In: Hoar, W.S., Randall, D.J., Brett, J.R. (eds.), Fish Physiology, Academic Press Inc., New York, USA, pp. 456598.

Ebada, A.F.E.A. 2004. Studies on tilapia fish. Ph.D. in Agricultural Sciences, Animal Production Department, Fac. of Agric. Al-Mansoura University, Egypt.

El-Sayed, A.F.M., 2006. Tilapia culture. CAB International, Wallingford, UK. 277p.

Fashina-Bombatta, H.A. and Megbowon, I., 2012. Proximate composition and breeding description of an unidentified cichlid of Epe lagoon, Lagos, Southwest Nigeria, commonly called "Wesafu", Int. J. Nutrition. Metabolism, 4(4), 57-63.

Gale, W.L., Fitzpatrick, M.S., Lucero, M., Contreras-Sanchez, W.M. and Schreck, C.B., 1999. Masculinization of Nile tilapia (Oreochromis niloticus) by immersion in androgens. Aquaculture, 178, 349-357.

Genten, F. Terwinghe, E. and Danguy, A. 2009. Atlas of Fish Histology, $1^{\text {st }}$ Ed., Science Publishers, Enfield, NH, USA, 219 p.

Higgs, D.A., Fagerlund, U.M., McBride, J.R., Dye, H.M. and Donaldson, E.M., 1977. Influence of combinations of bovine growth hormone, 17a-methyltestosterone and L-thyroxine on growth of yearling coho salmon (Oncorhynchus kisutch). Can. J. Zool., 55(6), 1048-1056.

Kosia, P., Jiraungkoorskul, W., Sachamahithinant, C. and Jiraungkoorskul, K., 2011. Induction of testis-ova in Nile tilapia (Oreochromis niloticus) exposed to $17 \beta$-estradiol. Natural Science, 3 (3), 227-233.

Loir, M. 1999. Spermatogonia of rainbow trout: I. Morphological characterization, mitotic activity and survival in primary cultures of testicular cells. Molecular Reproduction and Development, 53, 422-433.

Lone, K.P. and Matty, A.J., 1980. The effect of feeding methyltestosterone on the growth and body composition of common carp (Cyprinus carpio L). Gen. Comp. Endocrinol., 40, 409424.

Magouz, F.I., El-Harairy, M.A., Abdel-Khalek, A.E. and Ebada, A.F., 2000. Effect of hormonal treatment on production of mono-sex males tilapia (Oreochromis niloticus). J. Agric. Sci. Mansoura Univ., 25, 7577- 7590.

Marjani, M., Jamili, S., Mostafavi, P.G., Ramin, M. and Mashinchian, A., 2009. Influence of 17-Alpha Methyl Testosterone on Masculinization and Growth in Tilapia (Oreochromis mossambicus). J. Fish. Aquat. Sci., 4 (I), 71-74.

Megbowon, I. and Mojekwu, T.O., 2014. Tilapia sex reversal using methyl testosterone (MT) and its effect on fish man and environment. Biotechnology, 13(5), 213-216.

Mires, D., 1995. The tilapias. In: Nash, C.E., Novotny, A.J. (eds.), Production of Aquatic Animals. Elsevier, New York, USA, pp. 133-152.

Miura, T. and Miura, C., 2001. Japanese eel: a model for analysis of spermatogenesis. Zoological Society of Japan, Zoological Science, 18 (8), 1055-1063.

Miura, T., Yamauchi, K., Takahashi, H. and Nagahama, Y. 1991. Hormonal induction of all 
stages of spermatogenesis in vitro in the male Japanese eel (Anguilla japonica). Proc. Nati. Acad. Sci. USA, 88, 5774-5778.

Msiska, O.V., 2002. The histology of mature gonads of Oreochromis (Nyasalapia) karongae (Trewavas). East African Wild Life Society, Afr. J. Ecol., 40, 164-171.

NRC. 2011. Nutrient Requirements of Fish and Shrimp. The National Academics Press, Washington, DC., USA, 57p.

Pudney, J., 1995. Spermatogenesis in nonmammalian vertebrates. Microscopy Research and Technique, 32, 459-497.
Schulz, R.W., de França, L.R., Lareyre, J.J., LeGac, F., Chiarini-Garcia, H., Nobrega, R.H. and Miura, T. 2010. Spermatogenesis in fish. General and Comparative Endocrinology, 165, 390-411.

Workagegn, K.B., Ababboa, E.D., Yimer, G.T. and Amare, T.A. 2014. Growth Performance of the Nile Tilapia (Oreochromis niloticus L.) Fed Different Types of Diets Formulated from Varieties of Feed Ingredients. J. Aquac. Res. Development, 5 (3), 235, 1-4. 



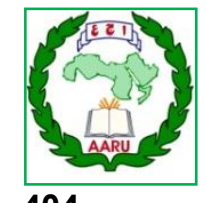

المؤتمر الرابع عثر لبحوث التنمية الزراعية،

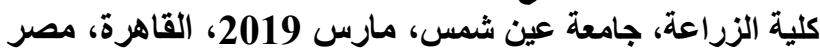

مجلد(27)، عدد (1)، عداعد خاص مارس، مارس 2019 (104-395، 2019

Website: http://strategy-plan.asu.edu.eg/AUJASCl/

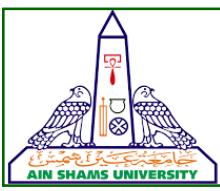

دراسة تقيمية لأداء النمو وتطور الغدد التناسلية للبلطي النيلي آحادي الجنس في المراحل العمرية المختلفة خلال فترة الإنتاج

سارة شحات النحال" - محمد عبد الباقى عامر - محمد فتحى عثمان - طارق أبو المكارم على القى قسم الإنتاج الحيوانى- كلية الزراعة - جامعة عين شس ، ص ب: 68 حائق شبرا، 11241، القاهرة، مصر

*Corresponding author: sarashahat@agr.asu.edu.eg

Received 3 March, 2019, $\quad$ Accepted 12 March, 2019

التدهور فبزيادة الوزن والعمر استمرت عملية نمو الفور الفيات

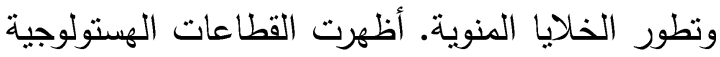

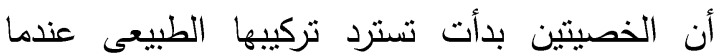
وصلت الأسماك لعمر 4-5 شهور

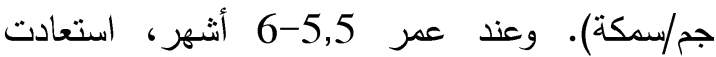
الأسماك البنية الطبيعية لخصيتيها بشكل كامل واتضح

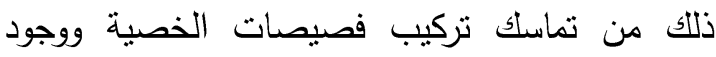

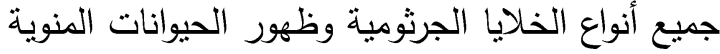

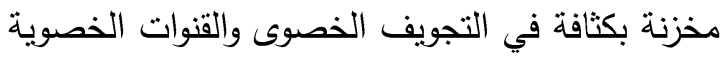

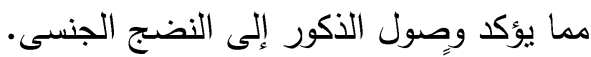
استتادا إلى النتائج المتحصل علئ اليها، يمكن استنتاج

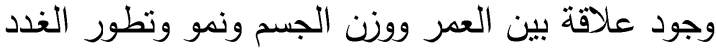

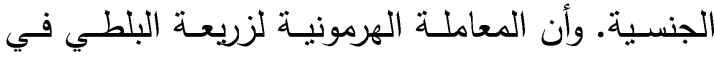

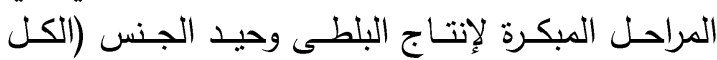

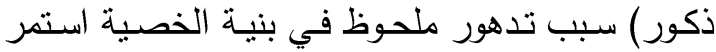

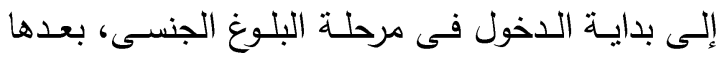

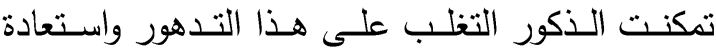

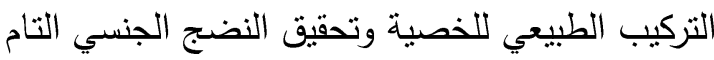
عند عمر يتراوح من 5.5 إلى 6 شهور

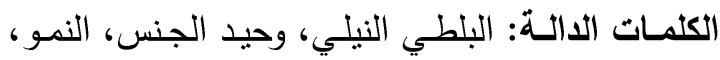
قطاعات هيستولوجية في الغدد الجنسية

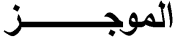

تم تصميم هذه الدراسة لتقييم أثر التغذية بعليقة تجارية خلال دورة الإنتاج على تطورِ الغدد التتاسلية

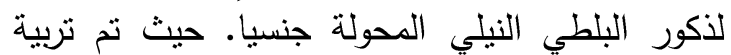

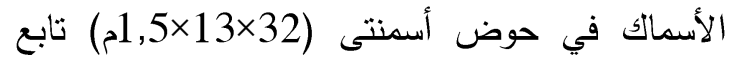

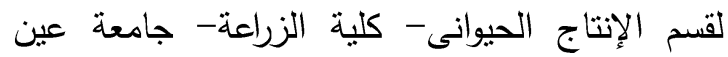
شمس. وتم تغذية الأسماك على عليقة تجارية (30 \%

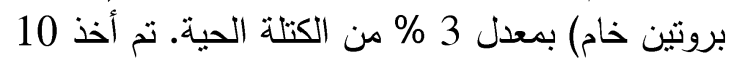
أسماك كعينة عشوائية كل أسبوعين طوال الفترة

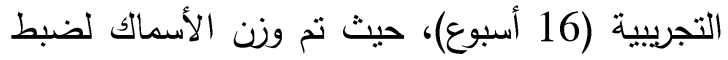
نسب التخذية وحساب مقاييس النمو. كذلك تم إجراء الفحص النسيجي للغدد التتاسلية كل أسبوعين لتتبع

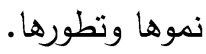
أظهرت النتائج وجود علاقة بين نمو الأسماك

وتطور الغدد التناسلية خلا وجل الفترات العمرية المختلفة لأنة

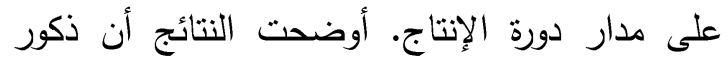
البلطى النيلى المحولة جنسيا استطاعت مضاعلى النقاعة وزنها

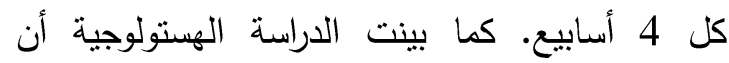

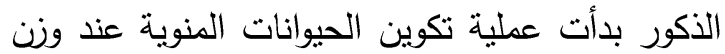
جسم 29,16جم. أثناء تلأك المرحلة العهرية، أظهرت الكرات الثرية

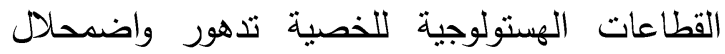

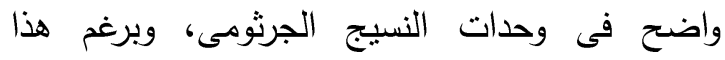

